\title{
Melanoma of the Ciliary Body and Choroid pT3b TNM Finding v7
}

National Cancer Institute

\section{Source}

National Cancer Institute. Melanoma of the Ciliary Body and Choroid pT3b TNM Finding v7. NCI Thesaurus. Code C88698.

Tumor size category 3 with ciliary body involvement. (from AJCC 7th Ed.) 